\title{
Identifying the Effective Factors on Brand Equity from Consumers Perspective Using Aaker Model: A Case of Tehran Dairy Products
}

\author{
Jamshid Jafari Darabjerdi ${ }^{1}$, Masoud Arabi ${ }^{1}$ \& Maryam Haghighikhah ${ }^{2}$ \\ ${ }^{1}$ Department of Management, Hormozgan University, Bandar Abbas, Iran \\ ${ }^{2}$ Faculty of Management and Accounting, Tehran University, Tehran, Iran \\ Correspondence: Masoud Arabi, Department of Management, Hormozgan University, Bandar Abbas, Iran. Tel: \\ 98-910-164-5922. E-mail: y.mh.6204@gmail.com
}

Received: January 26, 2016

doi:10.5539/ijbm.v11n4p265
Accepted: February 27, 2016

Online Published: March 15, 2016

URL: http://dx.doi.org/10.5539/ijbm.v11n4p265

\begin{abstract}
Brands are differentiating aspect of products. So, identifying the effective factors in creating brand value and evaluating the value is of great importance. The present study, using structural equation modeling, attempts at investigating and explaining effective factors on brand equity of dairy products with Aaker model. Participants are 381 consumers of Tehran dairy products and the variables of advertisement cost, attitude to advertisement, monetary promotions, non-monetary promotions, packaging and distribution span on perceived dimensions of brand equity including brand awareness, brand associations and the perceived quality were measured. The results showed that variable of brand awareness had the highest explanatory role. Also according to the results, the effects of attitude to advertising on perceived quality and brand awareness, packaging on brand awareness, advertising cost on brand association, non-monetary promotions on brand association and distribution spread on brand association were not supported.
\end{abstract}

Keywords: brand equity, advertisement, promotions, packaging, distribution

\section{Introduction}

\subsection{Brand Equity and Its Advantages}

Brands are the beginning of relation making process between consumers and products or services. In consuming market, brand is the main differentiating point for products. The most outstanding feature of a professional marketer is to create a brand, protect it, and support it. Brand is name, phrase, expression, sign, symbol, code, plan or a mixture of them to recognize the products and goods of sellers or a group of sellers and differentiating them from other competitive products. So, the reagent brand is the maker or seller of every product or service. The consumers consider the brand as an important part of every product and determining the brand can increase the value of every product (Kotler \& Armstrong, 2013). The attempt to define the relationship between customers and brands created "Brand Equity" in marketing literature (Wood, 2000). The concept of brand equity has attracted lots of attention after being introduced in business world and has been the base of lots of studies. Modern theories of marketing consider brand equity as key asset for companies. Probably this level of brand equity desirability is its key and strategic role in making managerial and marketing decisions and consequently gaining competitive advantage.

The present study serves two main purposes: first, investigating the dimensions of brand equity and second, identifying the variables of marketing mix on brand equity. To this end, first reviewing the literature on marketing, a conceptual model is introduced and then, research hypotheses and method are explained briefly. Then the results are interpreted and explained and some suggestions are presented.

Operationalizing brand equity is done in two ways in marketing studies. Those who investigate consumer's understanding such as brand awareness, brand associations and the perceived quality and those who investigate consumer's behavior such as loyalty, tendency to pay additional price and etc. these two methods are considered later in this research.

Keller (1991, 2003) is among the first scholars who proposed hypotheses on conceptualizing from consumer's perspective. He hypothesized that brand equity depends on brand knowledge and comparing it with a similar nameless product. He defined brand equity as distinctive effect of brand knowledge and reaction of consumer to 
its marketing. He also conceptualized brand knowledge based on brand knowledge and brand image (Keller, 2003).

Aaker tried to mix perceptive and behavioral dimensions and defined customer equity as the value customers associate with the brand in which brand awareness, brand associations, brand perceived quality and brand loyalty are reflected. Aaker considered the first three dimensions as perceptive and the fourth one as behavioral-attitude (Pradhan \& Prasad Misra, 2014). In lots of texts, equity has been considered as synonymous loyalty with equity.

Keller believed that when customers associate special brands with positive equity, it means that they react to marketing activities when the brand is named. He stated that customer positive equity can lead to more income, less costs and higher profits which directly imply company's ability in gaining higher price, the tendency and eagerness of customers in search of distribution channels, effectiveness of marketing communications and achievement of brand generalizations and licensing.

Aaker stated that brand equity creates the cash flow for companies because brand loyalty increases the effectiveness and efficiency of marketing planning and decreases the promotional costs dependence (Aker, 1996). It also provides a place for growth through generalization of brands and creates competitive advantage to put real obstacles to competitive brands (Mohamed Riaz et al., 2014).

High brand equity causes the customers believe in extraordinary claims of advertisements with higher prospects. It also declines the negative effects of customer selection from unattractive sale promotions and finally, it limits the negative reasoning after price increase. Generally, it can be said that brand equity increases customer value, helps creating defendable competitive opportunities and makes them accept the advertisements and promotions easier and facilitates penetrating in to the markets (Delgado \& Munuera, 2005).

Generally, brand equity has the following effects for the company:

1-Customer readiness for paying higher prices, 2-licensing the brand, 3-efficiency of marketing communications and shops readiness for participation support, 4-Consumer's tendency to price decrease, 5-Increasing customer's inattention to price increase and decreasing companies vulnerability against the crises.

Aaker stated that brand equity can increase customer value through processing, information interpretation, purchase decision confidence and use satisfaction (Baldauf et al., 2003). It should be noted that from consumer's perspective, brand equity can promote consumer's ability in interpreting and saving a great volume of information on the product. This study investigates effective variables on perceptive dimensions from Aaker's perspective. To this end, a collection of marketing mix is compiled and its effects on perceived quality, brand awareness, and brand association are measured.

\subsection{Brand Equity and Its Resources}

State why the problem deserves new research. For basic research, the statement about importance might involve the need to resolve any inconsistency in results of past work and/or extend the reach of a theoretical formulation. For applied research, this might involve the need to solve a social problem or treat a psychological disorder. When research is driven by the desire to resolve controversial issues, all sides in the debate should be represented in balanced measure in the introduction. Avoid animosity and ad hominem arguments in presenting the controversy. Conclude the statement of the problem in the introduction with a brief but formal statement of the purpose of the research that summarizes the material preceding it. For literature reviews as well as theoretical and methodological articles, also clearly state the reasons that the reported content is important and how the article fits into the cumulative understanding of the field.

\subsection{Brand Equity Effective Factors}

Brands are managed as long-term assets. Brand management should be strategic and totalizing. Marketing mix should be in the way that support brand message (Wood, 2000). Customers relate the value of a product with its brand. Brand can transfer positive or negative messages to customer's minds which depend on advertisement and sale promotion programs, product fame, evaluation and experience of using the products (Cateora, Gilly, \& Graham, 2010). It is important to know that marketing activities like packaging, brand name, density of distribution network, advertisement, permanent exhibitions, supports, and bulletins can help creating capital and long-term success like brand equity and customer satisfaction (Angulo, 2005).

Marketing mix elements increase consumer's perceptive equity to brands. For example, Yoo concluded that advertisement span and advertisement costs affect brand equity positively while price promotions and pricing policies affect negatively (Pappu et al., 2006). Some of the researcher found that advertisement has positive effect on brand equity. Exposure of consumers to a repetitive advertisement of a brand can lead to higher levels 
of brand equity. With increasing brand awareness, development of desirable associations and improvement of qualitative perceptions are resulted (Pappu \& Quester, 2008).

Marketing activities may have inverse effects on brand value. Aaker investigated the re-positioning of brands and the effects of brand image and brand equity from price discount. He suggested that if the price is only base of competition, such movements only nullifies the form of distinction and affect inversely on brand equity (Eagle et al., 2001). Law and Moor reported that companies which allocate higher budgets to advertisement and sale promotion attract more customers with more powerful and desirable brand equity. So, market share increases and profits go up (Teo \& Tan, 2002). Lots of other researchers found that the primary goals of sponsors are increasing brand awareness and development of brand or the image of the company. In lots of marketing forms, one of the primary goals of events sponsors is helping brand equity (Ray \& Cornwell, 2003). According to Yoo and Donthu, brand equity is made, kept and developed through strengthening of brand equity aspects which resulted from special marketing activities (Yoo \& Donthu, 2002). In general, most of brand equity research has focused on marketing mix variables such as advertisement, distribution, product quality and price as effective factors on brand equity (Yasin et al., 2007).

This study considers perceptive dimensions of brand equity from Aaker perspective including brand awareness, brand association and perceived quality and its effective factors including advertisement costs, the attitude to advertisement, packaging, monetary and non-monetary promotions and distribution extent.

Advertisement is an important external simulator which is sign of product quality. The expensive costs of advertisements show that company invests in brand referring to superior quality. So, advertisement costs are connected to perceived quality so that it leads to brand equity. Advertisements have central role in increasing brand awareness and association of a strong brand (Zarbi, 2008) because investment of more advertisement helps correct identification and reminding of the brand and increase the territory and frequency of the brand which in effect leads to brand awareness. Also, advertisements can create desirable, strong and peculiar associations (Buil et al., 2013). So, the following relationships are hypothesized:

-The cost of advertisement affects perceived quality.

-The cost of advertisement affects awareness.

-The cost of advertisement affects brand association.

The previous studies have shown that personal attitude can have an important effect on increasing brand equity. The meaning of attitude to advertisement of assumptions is the perceptions and feelings of the viewer to the observed advertisement. The positive attitude exists when the consumer considers advertisement as a guide to facilitate the purchase process and increase of selection power and awareness. Negative attitude to advertisement occurs when the consumers consider the advertisements false not believing its messages. In this case, only the negative side of advertisement, its exploiting aspect and its utilitarian goals are considered (Buil et al., 2013). Positive attitude to advertisement cause the people to receive and evaluate the hidden messages positively and record the created awareness in the mind effectively. Positive and strong association to brand will be done by the persons having positive attitude to advertisements more probably.

In negative attitude to advertisement and considering them as tools for manipulation of public thought in purchase of unnecessary cases causes the brand to make an undesirable image in consumer's mind as a utilitarian instrument (Cobb-Walgern et al., 1995). In this case, the consumer memorizes the undesirable aspect of the brand according to selective theory and when he sees or hears the brand name, not a good and proper association is made. So, it is concluded that:

-Attitude to advertisement affects perceived quality.

-Attitude to advertisement affects brand awareness.

-Attitude to advertisement affects brand association.

It is believed that sale promotion especially price promotions such as price decrease in short term, e.g. for special sales, distribution go-between coupon, packaging coupon, interest free transactions, discount and repayment, weakens brand equity in spite of short term financial return (Zarbi, 2008). Price sale promotion has negative effect on brand association and perceived quality because consumers use external factor for understanding product quality and price progressions damage brand association (Buil et al., 2013). Sale promoting is not a very proper method for creating brand equity because it is imitated easily by competitors and only increases short-term performance through encouraging sale and brand change due to monetary reasons (Aaker, 1991). In long term monetary promotions cause a low-quality brand image. Moreover, alternative price promotions may 
endanger the brand because it confronts the consumers with unpredicted price changes and consider it as the instability of product price (Yoo et al., 2000). So, it can be said that:

-Monetary promotion affects perceived quality.

-Monetary promotion affects brand association.

Non-monetary promotions such as free gifts, free samples and competitions have increasing importance in promotional strategies. The recent studies show that non-monetary promotions help supporting brand equity because more associations in relation to brand personality creates pleasant experiences, emotions and feelings which cause desirable and positive associations on brands. So, it can be said that:

-Non-monetary promotion affects perceived quality.

-Non-monetary promotion affects brand association.

Packaging includes activities such as designing and producing the packs and finally labeling the products (Kotler \& Armstrong, 2013). Packaging controls a desirable mental image of the product and attracts the customers (Adeli \& Shabanpour, 2006). Nowadays, due to rigorous competition in all the fields, the necessity and the need to a strong identity for making relationship with customers is felt increasingly and packaging is an important factor in relationship with customers. Aaker and Keller consider packaging as an important factor on brand equity. Packaging transfers the producer's message to consumer and personalize the product. Packaging is the product's face because the purchaser identifies the product through packaging (Sarrafizadeh, 1995). Packaging is introducing the products to consumers and more sale and interest and creating facilitation and communicative-advertising feature. As a marketing tool, packaging helps the sale through protecting the product from purchase place and in all the stages; it is accompanied with product advertisement, image and message (Sokutifar, 1996). Packaging controls the presentation of an appropriate image of the product and attracts the customers immediately and encourages him to purchase as an effective facto. It introduces the product through design, lines, coloring and form and induces its decision to consumers (Adeli \& Shabanpour, 2006). Packaging shows the company's attention amount to consumer's expectations and it is the first thing seen by purchaser when buying a product (Rahimnia et al., 2008). So, it can be concluded that:

-Packaging affects the perceived quality.

-Packaging affects brand awareness.

-Packaging affects brand association.

When the products are distributed in lots of shops (Yoo et al., 2000), the repetition and exposure to the products improve brand association on behalf of consumers (Huang \& Sarigollu, 2012). If distributive covering is increased, the consumers have more time and receive more value for the product. Added value is often resulted from reduction of losing the consumers who want a product. Such an added value leads to customer satisfaction, higher perceived quality, higher brand loyalty and finally more brand equity (Zarbi, 2008). So, it can be concluded that:

-Distribution spread affects the perceived quality.

\subsection{Hypotheses of the Research}

According to relationships mentioned in section 1.3, the hypotheses and conceptual model of research are presented as:

H1: Advertisement cost affects perceived quality.

$\mathrm{H} 2$ : The attitude to advertisement affects perceived quality.

H3: Monetary promotion affects perceived quality.

H4: Non-monetary promotion affects perceived quality.

H5: Packaging affects perceived quality.

H6: Advertisement cost affects brand awareness.

H7: The attitude toward advertisement affects brand awareness.

H8: Packaging affects brand awareness.

H9: Distribution spread affects brand awareness.

H10: Distribution spread affects brand association.

H11: The attitude to advertisement affects brand association. 
H12: Monetary promotion affects brand association.

H13: Non-monetary promotion affects brand association.

H14: Packaging affects brand association.

H15: Distribution spread affects brand association.

H16: The perceived quality affects brand loyalty.

H17: Brand awareness affects brand loyalty.

H18: Brand association affects brand loyalty.

\section{Method}

The present study is descriptive-analytical regarding data collection and applied considering the goals. A survey among diary consumers was done to collect data.

A Likert-point scale questionnaire was used. The reliability was checked through Cronbakh alpha. Content validity was checked through expert opinion. Both reliability and validity were confirmed.

Factor analysis was used to evaluate the wanted factors and construct validity of the questionnaire. In factor analysis, the questions which have been raised to measure a construct should have a common factor loading. To this end, first using factor analysis, the measuring components of each of the variables were determined and then, research hypotheses were tested by structural equation modeling. Using Chokran's formula, sample size was determined 384 and 400 questionnaires were distributed. Totally, 381 questionnaires returned.

\section{Results}

To test the research hypotheses and analyze data, structural equation modeling was used.

The gender division showed that $43.4 \%$ of the participants were women and $56.6 \%$ were men. Age division showed that most of the participants (36.9\%) are 25-31 years old. Regarding education, it is shown that $50 \%$ of the participants had BA degree. The mean of the answers to the variables are: advertisement cost (3.613), attitude to advertisement (3.731), monetary promotions (3.321), non-monetary promotion (3.494), packaging (3.589), the perceived quality (2.889), brand awareness (3.46), brand association (3.231) and brand loyalty (3.233).

The results are shown in the following Table 1.

Table 1. Way coefficient, $t$ statistics and research hypotheses results

\begin{tabular}{|c|c|c|c|c|c|}
\hline \multicolumn{2}{|c|}{ Research hypotheses } & \multirow{2}{*}{$\begin{array}{l}\begin{array}{l}\text { Way } \\
\text { coefficient }\end{array} \\
0.26\end{array}$} & \multirow{2}{*}{$\begin{array}{l}\text { T statistics } \\
4.15\end{array}$} & \multirow[t]{2}{*}{$\begin{array}{l}\text { Determination } \\
\text { coefficient }\end{array}$} & \multirow{2}{*}{$\begin{array}{l}\text { Result } \\
\text { supported }\end{array}$} \\
\hline 1 & $\begin{array}{l}\text { Advertisement cost on } \\
\text { perceived quality }\end{array}$ & & & & \\
\hline 2 & $\begin{array}{l}\text { Attitude to advertisement on } \\
\text { perceived quality }\end{array}$ & 0.09 & 1.56 & \multirow{4}{*}{0.29} & rejected \\
\hline 3 & $\begin{array}{l}\text { Monetary promotion on } \\
\text { perceived quality }\end{array}$ & $0.17-$ & -2.85 & & supported \\
\hline 4 & $\begin{array}{l}\text { Non-monetary promotion on } \\
\text { perceived quality }\end{array}$ & 0.15 & 2.65 & & supported \\
\hline 5 & Packaging on perceived quality & 0.19 & 3.13 & & supported \\
\hline 6 & $\begin{array}{l}\text { Advertisement cost on brand } \\
\text { awareness }\end{array}$ & 0.16 & 2.42 & \multirow{4}{*}{0.22} & supported \\
\hline 7 & $\begin{array}{l}\text { Attitude to advertisement on } \\
\text { brand awareness }\end{array}$ & 0.08 & 1.31 & & rejected \\
\hline 8 & packaging on brand awareness & 0.08 & 1.35 & & rejected \\
\hline 9 & $\begin{array}{l}\text { Distribution span on brand } \\
\text { awareness }\end{array}$ & 0.25 & 3.94 & & supported \\
\hline 10 & $\begin{array}{l}\text { Advertisement cost on brand } \\
\text { association }\end{array}$ & 0.12 & 1.93 & \multirow{3}{*}{0.25} & rejected \\
\hline 11 & $\begin{array}{l}\text { Attitude to advertisement on } \\
\text { brand association }\end{array}$ & 0.15 & 2.53 & & supported \\
\hline 12 & Monetary promotion on brand & $0.18-$ & -2.81 & & supported \\
\hline
\end{tabular}




\begin{tabular}{|c|c|c|c|c|c|}
\hline & association & & & & \\
\hline 13 & $\begin{array}{l}\text { Non-monetary promotions on } \\
\text { brand association }\end{array}$ & 0.06 & 1.10 & & Rejected \\
\hline 14 & $\begin{array}{l}\text { packaging on } \\
\text { brand association }\end{array}$ & 0.16 & 2.63 & & Supported \\
\hline 15 & $\begin{array}{l}\text { Distribution span on } \\
\text { brand association }\end{array}$ & 0.02 & 0.36 & & Rejected \\
\hline 16 & $\begin{array}{l}\text { Perceived quality on } \\
\text { brand loyalty }\end{array}$ & 0.26 & 4.91 & & Supported \\
\hline 17 & $\begin{array}{l}\text { Brand awareness on } \\
\text { brand loyalty }\end{array}$ & 0.32 & 6.10 & 0.31 & Supported \\
\hline 18 & $\begin{array}{l}\text { Brand association on brand } \\
\text { loyalty }\end{array}$ & 0.23 & 4.32 & & Supported \\
\hline
\end{tabular}

\section{Discussion}

Advertisement cost has 0.26 direct effects on the perceived quality which is meaningful. This part is in line with Aaker model and Zarbi and Shams and Yoo et al studies.

The attitude to advertisement has 0.09 direct positive effect on the perceived quality which is not meaningful.

Monetary promotions have 0.17 direct negative effect on the perceived quality which is meaningful. This part is in line with Aaker model and Yoo et al model.

Monetary promotions have 0.15 direct positive effect on the perceived quality which is meaningful. This part is in line with Zarbi and Shams study.

Packaging has 0.19 direct positive effects on the perceived quality which is meaningful. This part is in line with Keller's model.

Advertisement cost has 0.16 direct positive effect on brand awareness which is meaningful. This part is in line with Keller's model and Gil et al study.

Attitude to advertisement has 0.86 direct positive effect on brand awareness which is not meaningful. This part is not in line with Gil et al and Zarbi and Shams studies.

Packaging has 0.16 direct positive effect on brand awareness which is not meaningful. This part is not in line with Keller's model (2003).

Distribution spread has 0.25 direct positive effect on brand awareness which is meaningful. This part is in line with Keller's model and Yoo et al study.

Advertisement cost has 0.12 direct positive effect on brand association which is not meaningful. This part is not in line with Keller's model, Zarbi and Shams and Gil et al studies.

Advertisement cost has 0.15 direct positive effect on brand association which is meaningful. This part is in line with Gil et al model.

Monetary promotion has 0.18 direct negative effect on brand association which is meaningful. This part is not in line with Zarbi and Shams and Gil et al studies.

Non-monetary promotion has 0.06 direct positive effect on brand association which is not meaningful. This part is not in line with Zarbi and Shams and Gil et al studies.

Packaging has 0.16 direct positive effect on brand association which is meaningful. This part is not in line with Keller's model (2003).

Distribution span has 0.02 direct positive effect on brand association which is not meaningful. This part is not in line with Yoo et al but zarbi and Shams study.

Advertisement cost has 0.26 direct positive effect on brand loyalty which is meaningful. This part is not in line with Keller (1993), Aaker (1996), Zeithamel (1998), Yoo et al. (2000; 2005), Zarbi (2008) and Shams (2008). This part is not consistent with Gil (2007), Atilgan (2005) and Shafieha (2008).

Brand awareness has 0.32 direct positive effect on brand loyalty which is meaningful. This part is not in line with Keller (1993; 1996), Aaker (1991; 1996), Yoo et al. (2000; 2005), and Shams (2008). This part is not 
consistent with Gil (2007), Atilgan (2005) and Shafieha (2008).

Brand association has 0.32 direct positive effect on brand loyalty which is meaningful. This part is not in line with Keller (1993; 1996), Aaker (1991; 1996), Yoo et al (2000; 2005), and Shams (2008). This part is not consistent with Gil (2007), Zarbi (2008) Atilgan (2005) and Shafieha (2008).

\section{Suggestion}

The followings are the suggestions of this study based on the results and the purposes:

1) Regarding the mean score of each component of brand equity variable, the directors should focus on promotional activities of brand equity to produce goods which are accepted on behalf of the customers and in other words have a successful brand generalization. Based on the mentioned points and previous studies on effective factors of brand equity, directors can have a correct and strategic planning and optimized use of the factors to increase their brand equity and gain more sustainable profits in competition markets. Regarding the results of the study and to increase brand equity, directors should strengthen brand awareness and association.

2) The results of way analysis showed that brand equity is influenced by brand awareness and association. Considering these factors shows that brand awareness had more effects than brand association. Recognizing the brand and remembering it are among brand awareness components and regarding the mean score of brand awareness, the companies should pay more attention to brand remembering. So, directors should use different tools for promoting consumer's brand awareness. One of these instruments is advertisement which causes customers have more familiarity with brands and see them in numerous situations. They remember the brands when decided to purchase. Another instrument is expanded distribution. The brads distributed more widely attract more association and familiarity on behalf of customers. However the sample of the product can familiarize the customers with the brand and increase his awareness. Moreover, the content of the products can be described well through catalogues and brochures and increase brand awareness.

3) Brand association components include brand personality and organizational association. Regarding the mean of brand association components, the companies should support organizational association to make the customers interest and attached to companies and trust the brand. So, the companies should develop strategies to increase brand attraction and attachment. Moreover, supportive programs (sport teams, cultural groups, art, etc.) or financing charities, participating in social activities and etc. can support organizational association. Brand identity which is among brand association elements should be noticed. In the present study brand identity included reliability, prestige, distinction and credibility. So, regarding the mean of the questions related to brand identity, the companies should act in a way to distinguish their brand for customers. So, using songs, ads or peculiar mottoes can distinguish the brands and special signs and symbols can be used to distinct the brands. Moreover, packaging, designs and colors can be used to be in line with regional cultures and prestigious. Shops can be used to supply the brands which their images in customers' mind be a symbol of prestige; because, good mental image attract more contact and visit on behalf of potential customers and create positive association in visitors' minds. Improving the quality of the product can attract customers trust. Using the famous artists and sportspersons can effective and useful in verifying the credibility and reliability of the brand.

4) Based on this study, packaging is an effective factor on brand association and perceived quality. Packaging components include packing, design, form and label. Regarding the score of these components, first designing the packs should be noticed. The concept of packaging design is inherently multi-dimensional including numerous elements such as text, shape, graphic design, logo, size, color, images, material, structure, texture and etc. so, in packaging design, presenting new, various and attractive designs shouldn't be forgotten. The shape of packaging should be attractive and appropriate. The color of packaging can be used for distinguishing the product. It is better to select energetic and happy colors for packaging. The label should carry useful information to introduce the content of the package properly. Especially for dairy products, the information on label should be comprehensive and complete. The studies on hemispheres of human brain show that brain perception is not symmetrical. For example, if the words are taken from right side of the brain, image or non-verbal signs are taken from the left side. So, to maximize the retentions, the words can be juxtaposed in the right side of the pack and the images on the left side.

5) Perceived quality is one of contributing factors on brand equity from Aaker's perspective. This study showed that the relationship between perceived quality and brand equity is not meaningful. Regarding the mean score of the questions related to perceived quality of the brand, the components of this variables have good score. It can be justified that customers consider the perceived quality necessary which doesn't cause brand equity. So, the product quality should be kept in a high level. 


\section{References}

Aaker, D. A. (1991). Managing Brand Equity. New York, NY: The Free Press.

Aaker, D. A. (1996). Building Strong Brands. New York, NY: The Free Press.

Adeli, A., \& Shabanpoor, B. (2006). The role of aquatics on the consumption behavior of Tehran families. Agricultural Sciences and Natural Resources, 14(1).

Angulo, L. F. (2005). The Effect of Marketing Effecting, Brand Equity and Customer Satisfaction on Firm Performance: An Economic Model and Data Envelopment Approach.

Atilgan, E., Aksoy, S., \& Akinci, S. (2005). Determinates of the Brand Equity: A Verification Approach in the Beverage Industry in Turkey. Marketing Intelligence \& Planning, 23(3), 237-248. http://dx.doi.org/10.1108/02634500510597283

Baldauf, A., Cravens, S. K., \& Binder, G. (2003). Performance Consequences of Brand Equity Management Evidence from Organization in the Value Chain. Journal of Product \& Brand Management, 12(4), 220-236. http://dx.doi.org/10.1108/10610420310485032

Bristow, D. N., Schneider, K. C., \& Schuler, D. K. (2002). The Brand Dependence Scale: Measuring Consumers' Use of Brand Name to Differentiate Among Product Alternatives. Journal of Product \& Brand Management, 11(6), 343-356. http://dx.doi.org/10.1108/10610420210445488

Buil, I., Chernatony, L. D., \& Martinez, E. (2013). Examining the role of advertising and sales promotions in brand equity creation. Journal of Business Research, 66, 115-122. http://dx.doi.org/10.1016/j.jbusres.2011.07.030

Cateora, Ph., Gilly, M., \& Graham, J. (2010). International marketing (15th ed.). McGraw-Hill

Cobb-Walgren, C. J., Ruble, C. A., \& Donthu, N. (1995). Brand Equity, Brand Preference, and purchase Intent. Journal of Advertising, 24(3), 25-40. http://dx.doi.org/10.1080/00913367.1995.10673481

Delgado-Ballester, E., \& Munuera-Aleman, J. L. (2005). Does Brand Trust Matter to Brand Equity? Journal of Product \& Brand Management, 14(3), 187-196. http://dx.doi.org/10.1108/10610420510601058

Eagle, L., Kitchen, P. J., Rose, L., \& Moyle, B. (2008). Brand Equity and Brand Vulnerability: The impact of gray marketing/parallel importing on brand equity and values. European Journal of Marketing, 37(10): 1332-1349. http://dx.doi.org/10.1108/03090560310487130

Gil, R. B., Andres, E. F., \& Salinas, E. M., (2007). Family as Source of Consumer-Based Brand Equity. Journal of Product \& Brand Management, 16(3), 188-199. http://dx.doi.org/10.1108/10610420710751564

Huang, R., \& Sarigollu, E. (2012). How brand awareness relates to market outcome, brand equity, and the marketing mix. Journal of Business Research, 65, 92-99. http://dx.doi.org/10.1016/j.jbusres.2011.02.003

Keller, K. L. (1993). Conceptualizing, measuring, and managing customer-based brand equity. Journal of Marketing, 57, 1-22.

Keller, K. L. (2003). Strategic brand management: Building, measuring, and managing brand equity (2nd ed.). Upper Saddle River, NJ: Prentice Hall.

Kotler, Ph., \& Armstrong, G. (2013). Principles of Marketing (15th ed.). Upper Saddle River, NJ: Prentice Hall.

Mohamed Riaz, M., Kumaresan, M., Aruna, K., Vibin, C. M., \& Raj, K. (2014). Consumer-Based Brand Equity: Improving the Measurement - Empirical Evidence. IOSR Journal of Business and Management, 16(5), 25-30. http://dx.doi.org/10.1108/10610420510601012

Pappu, R., \& Quester, P. G. (2008). Does Brand Equity Vary between Department Stores and Clothing Stores? Results of an Empirical Investigation. Journal of Product \& Brand Management, 17(7), 425-435. http://dx.doi.org/10.1108/10610420810916335

Pappu, R., Quester, P. G., \& Cooksey, R. W. (2006). Consumer-Based Brand Equity and Country-of-Origin $\begin{array}{lllll}\text { Relationships. } \quad \text { European Journal of } & \text { Marketing, } & \text { 40(5/6), }\end{array}$ http://dx.doi.org/10.1108/03090560610657903

Pradhan, J., \& Prasad Misra, D. (2014). Measuring Customer Based brand equities of FMCGs in Indian Rural Markets-An Empirical Study. International Journal of Business and Management Invention, 3(1), 51-62.

Rahimnia, F., \& Alavi, S. M. (2008). Investigating the effect of market competitive force on the strategies of product packaging using Porter competitive model. Commercial Research, 31. 
Rahimnia, F., Alavi, S. M., \& Najafi Siahroodi, M. (2008). Systematic approach in packaging management with presenting a comprehensive model in product packaging process. The 3rd conference on international marketing management, Tehran.

Ray, D. P., \& Cornwell, T. B. (2003). Brand Equity's Influence on Responses to Event Sponsorships. Journal of Product \& Brand Management, 12(6), 377-393. http://dx.doi.org/10.1108/10610420310498803

Rio, A. B., Vazquez, R., \& Iglesias, V., (2001). The Effects of Brand Association on Consumer Response. Journal of Consumer Marketing, 18(18), 410-425. http://dx.doi.org/10.1108/07363760110398808

Sarrafizadeh, M. H. (1995). Packaging and its role on exporting. International Congregation of Iran Food Industries.

Shafieha, R. (2008). Investigating the effective factors on mobile phone brand equity from customers' perspective based on Aaker's model. International conference of brand, Tehran.

Shams, R. (2008). Investigating the relationship between marketing activities and brand equity factors using generalized Aaker's model. International conference of brand, Tehran.

Sokutifar, R. (1996). The importance of packaging in marketing aquatics. The $6^{\text {th }}$ conference on Iran fisheries, Tehran.

Teo, T. H., \& Tan, J. (2002). Senior Executives Perception of Business-to-Consumer (B2C). Online Marketing Strategies: The Case of Singapore, 12(3), 258-275. http://dx.doi.org/10.1108/10662240210430937

Wood, L., (2000). Brands and Brand Equity: Definition and Management. Management Decision, 38(9), 662-669. http://dx.doi.org/10.1108/00251740010379100

Yasin, N. M., Noor, M. N., \& Mohamad, O. (2007). Does Image of Country-of-Origin Matter to Brand Equity? Journal of Product \& Brand Management, 16(1), 38-48. http://dx.doi.org/10.1108/10610420710731142

Yoo, B., \& Donthu, N. (2002). Testing Cross-Cultural Invariance of Brand Equity Creation Process. Journal of Product \& Brand Management, 11(6), 380-398. http://dx.doi.org/10.1108/10610420210445505

Yoo, B., Donthu, N., \& Lee, S. (2000). An examination of selected marketing mix elements and brand equity. Journal of the Academy of Marketing Science, 28(2), 195-211.

Zarbi, S. (2008). Evaluation of the effect of selected marketing mix on brand equity. Brand international conference.

Zeithaml, V. (1988). Consumer perceptions of price, quality, and value: A means-end model and synthesis of the evidence. Journal of Marketing, 52(3), 2-22. http://dx.doi.org/10.2307/1251446

\section{Copyrights}

Copyright for this article is retained by the author(s), with first publication rights granted to the journal.

This is an open-access article distributed under the terms and conditions of the Creative Commons Attribution license (http://creativecommons.org/licenses/by/3.0/). 